\title{
CLINICAL OUTCOME OF NEONATAL BACTERIAL MENINGITIS ACCORDING TO BIRTH WEIGHT
}

\author{
Vera Lúcia Jornada Krebs', Gleise Aparecida Moraes Costa²
}

\begin{abstract}
Objective: To describe the clinical outcome and the complications of bacterial meningitis according to birth weight of out born neonates admitted in intensive care unit during an 11 year-period. Method: Eighty-seven newborns were studied. Thirty-four infants were low birth weight newborn and 53 presented birth weight $\geq 2500 \mathrm{~g}$. The clinical data were obtained through the analysis of patients' files. Fisher's exact test, the $\chi^{2}$ and the Mann-Whitney test were applied. Results: Neurological symptoms were more common in infants weighed $\geq 2500 \mathrm{~g}(\mathrm{p}<0.05)$. Complications affected half of the cases in both groups. Complications affected half of the cases in both groups, with an overall mortality rate of $11.5 \%$. Conclusion: The rate of complications was high in both groups, regardless of the birth weight. No association was observed between the occurrence of death and birth weight. Infants with positive CSF culture had a poorer prognosis.
\end{abstract}

KEY WORDS: newborn, neonatal meningitis, central nervous system.

\begin{abstract}
Evolução clínica da meningite bacteriana neonatal de acordo com o peso de nascimento
RESUMO - Objetivo: Descrever a evolução clínica e as complicações da meningite bacteriana de acordo com o peso de nascimento em recém-nascidos admitidos em unidade de terapia intensiva externa durante o período de 11 anos. Método: Foram estudados 87 neonatos, dos quais 34 foram recém-nascidos de baixo peso e 53 apresentaram peso $\geq 2500 \mathrm{~g}$. Os dados clínicos foram obtidos por análise dos prontuários médicos. Foram realizados teste exato de Fisher, teste do $\chi^{2}$ e teste de Mann-Whitney. Resultados: Os sintomas neurológicos foram mais comuns em neonatos com peso $\geq 2500 \mathrm{~g}(p<0,05)$. As complicações ocorreram na metade dos casos em ambos os grupos, com mortalidade global de 11.5\%. Conclusão: A freqüência de complicações foi alta em ambos os grupos, independentemente do peso de nascimento. Não houve associação entre óbito e peso de nascimento. Os neonatos com cultura de líquor positiva apresentaram pior prognóstico.
\end{abstract}

PALAVRAS-CHAVE: recém-nascido, meningite neonatal, sistema nervoso central.

Low birth weight newborns present a 3 -fold increased risk of acquiring meningitis when compared to those whose birth weight is $\geq 2500 \mathrm{~g}^{1}$. Among very low birth weight neonates $(<1500 \mathrm{~g})$ the risk is a 10 to 17 -fold higher ${ }^{2-4}$. In addition to the immaturity of the immunological system, these neonates frequently present risk factors for infection related to maternal diseases or neonatal conditions ${ }^{1,3,5}$.

The objective of this study was to describe the clinical outcome and the complications of bacterial meningitis according to birth weight of out born neonates admitted in intensive care unit during an 11 year-period.

\section{METHOD}

Eighty-seven newborns with bacterial meningitis who were admitted to the Neonatal Intensive Care Unit (NICU) of the Instituto da Criança, Hospital das Clínicas, University of São Paulo, from January $1^{\text {st }}, 1994$ to December $31^{\text {st }}, 2004$ were studied. Thirty-four of the newborn were low birth weight newborn $(<2500 \mathrm{~g})$ and 53 presented birth weight $\geq 2500 \mathrm{~g}$. Neonates with meningomyelocele, hydrocephalus, perinatal asphyxia, congenital infection, nonbacterial infection and those with a prior history of surgical procedure in the central nervous system were excluded from the study. The clinical data were obtained through the analysis of patients' files.

The diagnosis of meningitis was based on either the presence of bacteria in the cerebrospinal fluid (CSF) or CSF with an increase in the number of cells $\left(>20\right.$ cells $\left./ \mathrm{mm}^{3}\right)$, predominance of neutrophils, increase in the concentration of protein $(>100 \mathrm{mg} / \mathrm{dL})$ and reduction in the concentration of glucose $(<50 \% \text { of the concomitant glycemia })^{6,7}$.

Ampicillin and third-generation cephalosporins were administered immediately after the lumbar puncture was performed. When necessary, therapy was changed based on the result of cultures and maintained for at least 21 days.

Fisher's exact test, the chi-square and the Mann-Whitney test were applied for statistical analysis. $p$ values $<0.05$ were considered statistically significant.

Departamento de Pediatria, Faculdade de Medicina da Universidade de São Paulo, São Paulo SP, Brasil (FMUSP): 'Livre-docente em Medicina pela FMUSP, Chefe do Berçário Anexo à Maternidade do HCFMUSP; ${ }^{2}$ Mestre em Ciências pela FMUSP.

Received 12 September 2006, received in final form 4 September 2007. Accepted 29 September 2007.

Dra. Vera Lúcia Jornada Krebs - Rua lara 123 / 51 - 04542-030 São Paulo SP - Brasil. E-mail: verakrebs@uol.com.br 
The study was approved by the Research and Ethics Committee of the Department of Pediatrics of São Paulo University School of Medicine and by the Ethics Committee for the Analysis of Projects and Research of the Hospital das Clínicas.

\section{RESULTS}

Among the 87 neonates with bacterial meningitis, $53(61 \%)$ presented birth weight $\geq 2500 \mathrm{~g}$ and 34 (39\%) were low birth weight newborns, including 15 very low birth weight (<1500 g) infants. The age at diagnosis, duration of treatment and gender are shown in Table 1. There was no statistically significant difference in the duration of the treatment between the newborns presented birth weight $\geq 2500 \mathrm{~g}$ and the low birth weight newborns $(p=0.196)$.

Fever, irritability, seizures and a bulging fontanel were significantly more frequent among newborns whose birth weight was $\geq 2500$ g, whereas abdominal distension, apnea, jaundice and blood count abnormalities were predominant among low-birth weight newborns (Table 2).

Etiological agents identified at the CSF and blood cultures are shown in Table 3. Bacteria in the CSF were identified in 34 (39\%) of the newborn, 17 (50\%) were gram-positive and 17 (50\%) gram-negative bacteria, with no difference regarding the type of bacteria and birth weight $(p=0.688)$.

Table 1. Age at diagnosis, duration of treatment and gender in 87 newborns with bacterial meningitis according to birth weight.

\begin{tabular}{lccc}
\hline & \multicolumn{2}{c}{ Birth weight $(\mathrm{g})$} & \\
\cline { 2 - 3 } Variables & $<2500(\mathrm{~N}=34)$ & $\geq 2500(\mathrm{~N}=53)$ & Total $(\mathrm{n}=87)$ \\
\hline Age at diagnosis $(\mathrm{d}) *$ & $7.4(0-29)$ & $12.9(1-28)$ & $10.8(0-29)$ \\
Duration of treatment $(\mathrm{d})$ & $29.1(2-98)$ & $21.6(1-48)$ & $24.5(1-98)$ \\
Female & $22(25 \%)$ & $25(32 \%)$ & $50(57 \%)$ \\
Male & $12(14.7 \%)$ & $25(29 \%)$ & $37(43 \%)$ \\
\hline
\end{tabular}

d, days; *mean (minimum-maximum).

Table 2. Comparision of the clinical signs in 87 newborns with bacterial meningitis according to birth weight.

\begin{tabular}{|c|c|c|c|c|}
\hline \multirow[b]{3}{*}{ Clinical signs* } & \multicolumn{2}{|c|}{ Birth weight (g) } & \multirow[b]{3}{*}{$\mathrm{p}$} & \multirow{3}{*}{$\begin{array}{c}\text { Total }(n=87) \\
n(\%)\end{array}$} \\
\hline & $<2500(n=34)$ & $\geq 2500(n=53)$ & & \\
\hline & $\mathrm{n}(\%)$ & $\mathrm{n}(\%)$ & & \\
\hline Fever & $16(47.1)$ & $39(73.6)$ & $55(63.2)$ & 0.012 \\
\hline Irritability & $3(8.8)$ & $24(45 \cdot 3)$ & $27(31.0)$ & $<0.001$ \\
\hline Seizures & $4(11.8)$ & $22(41.5)$ & $26(29.9)$ & 0.003 \\
\hline Lethargy & $9(26.5)$ & $14(26.4)$ & $23(26.4)$ & 0.995 \\
\hline Food refusal & $7(20.6)$ & $13(24.5)$ & $20(23.0)$ & 0.670 \\
\hline Bulging fontanel & $3(8.8)$ & $16(30.2)$ & $19(21.8)$ & 0.019 \\
\hline Moaning & $4(11.8)$ & $14(26.4)$ & $18(20.7)$ & 0.100 \\
\hline Tachypnea & $8(23.5)$ & $7(13.2)$ & $15(17.2)$ & 0.214 \\
\hline Cyanosis & $6(11.6)$ & $8(15.1)$ & $14(16.1)$ & 0.752 \\
\hline Abdominal distension & $8(23.5)$ & $2(3.8)$ & $10(11.5)$ & 0.012 \\
\hline Vomiting & $3(8.8)$ & $7(13.2)$ & $10(10.3)$ & 0.734 \\
\hline Apnea & $7(20.6)$ & $2(3.8)$ & $9(8.0)$ & 0.025 \\
\hline Jaundice & $6(17.6)$ & $1(1.9)$ & $7(8.0)$ & 0.013 \\
\hline Skin lesions & $2(5.9)$ & $4(7 \cdot 5)$ & $6(4.6)$ & 1.000 \\
\hline Opisthotonos & $1(2.9)$ & $2(3.8)$ & $3(3.4)$ & 1.000 \\
\hline Diarrhea & $0(0.0)$ & $3(5.7)$ & $3(3.4)$ & 0.277 \\
\hline Hypothermia & $2(5.9)$ & $0(0.0)$ & $2(2.3)$ & 0.150 \\
\hline Digestive bleeding & $1(2.9)$ & $0(0.0)$ & $1(1.1)$ & 0.391 \\
\hline Metabolic disorder & $1(2.9)$ & $0(0.0)$ & $1(1.1)$ & 0.391 \\
\hline
\end{tabular}

*Neurological findings in $36.8 \%$ of the newborns. 
Table 3. Etiological agents identified at the cerebrospinal fluid (CSF) and blood cultures of 87 newborns with bacterial meningitis.

\begin{tabular}{|c|c|c|c|c|}
\hline \multirow[b]{4}{*}{ Bacteria } & \multicolumn{2}{|c|}{ CSF culture } & \multicolumn{2}{|c|}{ Blood culture } \\
\hline & \multicolumn{2}{|c|}{ Birth weight (g) } & \multicolumn{2}{|c|}{ Birth weight (g) } \\
\hline & $<2500$ & $\geq 2500$ & $<2500$ & $\geq 2500$ \\
\hline & $\mathrm{n}(\%)$ & n (\%) & $\mathrm{n}(\%)$ & $\mathrm{n}(\%)$ \\
\hline Streptococcus $B$ & $0(0.0)$ & $6(11.3)$ & $1(2.9)$ & $2(3.8)$ \\
\hline Staphylococcus aureus & $2(5.9)$ & $2(3.8)$ & $1(2.9)$ & $3(5.7)$ \\
\hline Staph. coagulase negative & $0(0.0)$ & $0(0.0)$ & $2(5.9)$ & $4(7.5)$ \\
\hline Klebsiella sp & $1(2.9)$ & $2(3.8)$ & $3(8.8)$ & $1(1.9)$ \\
\hline Acinetobacter sp & $2(5.9)$ & $1(1.9)$ & $1(2.9)$ & $0(0.0)$ \\
\hline Neisseria meningitidis & $1(2.9)$ & $2(3.8)$ & $1(2.9)$ & $0(0.0)$ \\
\hline Escherichia coli & $0(0.0)$ & $2(3.8)$ & $\circ(0.0)$ & $1(1.9)$ \\
\hline Streptococcus pneumoniae & $0(0.0)$ & $2(3.8)$ & $\circ(0.0)$ & $0(0.0)$ \\
\hline Streptococcus viridans & $1(2.9)$ & $1(1.9)$ & $0(0.0)$ & o (o.o) \\
\hline Pseudomonas sp & $0(0.0)$ & $0(0.0)$ & $1(2.9)$ & $0(0.0)$ \\
\hline Enterobacter sp & $0(0.0)$ & $1(1.9)$ & $0(0.0)$ & $1(1.9)$ \\
\hline Serratia marcescens & $0(0.0)$ & $1(1.9)$ & $0(0.0)$ & $0(0.0)$ \\
\hline Proteus sp & $0(0.0)$ & $1(1.9)$ & $\circ(0.0)$ & $0(0.0)$ \\
\hline Enterococcus fecalis & $0(0.0)$ & $1(1.9)$ & $\circ(0.0)$ & $0(0.0)$ \\
\hline Citrobacter sp & $0(0.0)$ & $1(1.9)$ & $0(0.0)$ & $0(0.0)$ \\
\hline Streptococcus pyogenes & $0(0.0)$ & $1(1.9)$ & $\circ(0.0)$ & $0(0.0)$ \\
\hline Streptococcus mitis & $0(0.0)$ & $1(1.9)$ & $\circ(0.0)$ & $0(0.0)$ \\
\hline Alcaligenes sp & $1(2.9)$ & $0(0.0)$ & $0(0.0)$ & $0(0.0)$ \\
\hline Gram-negative bacilli & $0(0.0)$ & $1(1.9)$ & $0(0.0)$ & $0(0.0)$ \\
\hline Total & $8(23.5)$ & $26(49.1)$ & $10(2.9)$ & $12(22.6)$ \\
\hline
\end{tabular}

Table 4. Comparision of the frequency of complications in 87 newborns with bacterial meningitis according to birth weight.

\begin{tabular}{lcccc}
\hline & \multicolumn{2}{c}{ Birth weight $(\mathrm{g})$} & & \\
\cline { 2 - 3 } Complications & $<2500(\mathrm{n}=34)$ & $\geq 2500(\mathrm{n}=53)$ & Total $(\mathrm{n}=87)$ & $\mathrm{p}$ \\
Seizures & $\mathrm{n}(\%)$ & $\mathrm{n}(\%)$ & $\mathrm{n}(\%)$ & $\mathrm{n}(\%)$ \\
Intracranial hemorrhage & $4(11.8)$ & $22(41.5)$ & $26(29.9)$ & 0.003 \\
Hydrocephaly & $9(26.5)$ & $5(9.6)$ & $14(16.1)$ & 0.035 \\
Death & $6(17.6)$ & $6(11.3)$ & $12(13.8)$ & 0.526 \\
Ventriculitis & $5(14.7)$ & $5(9.4)$ & $10(11.5)$ & 0.503 \\
Brain abscess & $4(4.8)$ & $5(9.4)$ & $9(10.3)$ & 0.732 \\
Sagittal venous sinus thrombosis & $1(2.9)$ & $2(3.8)$ & $3(3.4)$ & 1.000 \\
Cerebral infarction & $0(0.0)$ & $3(5.7)$ & $3(3.4)$ & 0.277 \\
Inappropriate ADH* secretion & $0(0.0)$ & $3(5.7)$ & $3(3.4)$ & 0.277 \\
Total without complications & $0(0.0)$ & $2(3.8)$ & $2(2.3)$ & 0.518 \\
Total with complications & $17(50.0)$ & $27(50.9)$ & $44(50.6)$ & 1.000 \\
\hline
\end{tabular}

*Antidiuretic hormone

The bacteria most frequently identified in the CSF were Enterobacteria ( $41 \%$ of the cases, Table 3 ), followed by Streptococcus B (17.5\%), non-B-type strain Streptococcus (17.5\%), Staphylococcus aureus (11.7\%), Neisseria meningitidis (8.8\%) and Enterococcus faecalis ( $3 \%)$.

Among the neonates with a positive CSF culture, mortality rate was $20.5 \%$ versus only $5.6 \%$ among those with a negative CSF culture, showing an association between the presence of bacteria in the CSF and complications $(p=0.008)$ or death $(p<0.043)$. The frequency of neurological complications were similar in the two groups, regardless of the birth weight (Table 4).

\section{DISCUSSION}

The most frequent clinical findings were non-specific, confirming the difficulty of attaining an early diagnosis of neonatal meningitis, due to the absence 
of neurological signs in the acute phase of the infectious process ${ }^{8,9}$. Fever, irritability, seizures and a bulging fontanel were significantly more frequent among newborns whose birth weight was $\geq 2500$ g, whereas abdominal distension, apnea, jaundice and blood count abnormalities were predominant among low birth weight newborns. It is possible that the neonates whose birth weight is $\geq 2500$ g present seizures more often due to the relative maturity of the central nervous system, when compared to the low-birth weight neonates. The low frequency of neurological findings makes diagnosis of bacterial meningitis more difficult in low birth weight newborns that in infants whose birth weight was $\geq 2500 \mathrm{~g}$.

Suspicion of bacterial infection is usually confirmed, although not consistently by positive results of cultures of CSF or blood. The identification of the bacteria in the CSF culture is considered the most accurate method for diagnosing bacterial meningitis. The CSF culture was positive in $39 \%$ of the neonates and the blood culture obtained at the same day from the CSF sample was positive in $17.2 \%$ of the cases. These results support the findings of Garges et al. ${ }^{9}$, which report a considerable number of neonates with a positive CSF culture and a negative blood culture. In $26.4 \%$ of the infants, only CSF was positive, with negative blood culture. According these authors, if the spinal tap had been carried out only in patients with a positive blood culture, $61 \%$ of the newborn would have gone undiagnosed.

As for the etiological agent, there was no association between the type of bacteria (gram-positive or gram-negative bacteria) and birth weight. The etiological agents most commonly identified in patients with a positive CSF culture were enterobacteria ( $41 \%)$, followed by Streptococcus B (17.6\%) and other Streptococcus (17.6\%). Streptococcus B was not identified in low-birth weight newborns, suggesting that in this group of neonates, meningitis was more associated to nosocomial infection than to vertical transmission. Neisseria meningitidis, considered a rare agent of CNS infection in the neonatal age, was found in 3 cases $(8.8 \%)$. The predominance of enterobacteria in our patients is supported by other studies ${ }^{10,11}$, which show that these microorganisms are the main etiological agents of bacterial meningitis in the neonatal period in developing countries.

Complications affected half of the cases in both groups, with an overall mortality rate of $11.5 \%$. Differently from what would be expected, no association was observed between the occurrence of complications or death and birth weight, although the percentage of low birth weight newborns who died $(14.7 \%)$ was higher than the percentage found in infants whose birth weight was $\geq 2500 \mathrm{~g}$ (9.4\%).

Despite the decrease in mortality rate compared to prior studies conducted at the same Service, which showed mortality rates of $29 \%^{10}$ and $26 \%^{12}$, the complications affected $50 \%$ of the patients in both groups. Others authors have emphasized the high morbidity of neonatal bacterial meningitis ${ }^{11-13}$, regardless of the decrease in the mortality. A surveillance study carried out in 2000 and 2001 revealed a mortality rate of $12.4 \%$ for meningitis due to $B$ Streptococcus infection in England and Ireland and of $8 \%$ in the USA $^{13}$. Despite the decline in mortality, morbidity did not change significantly between 1970 and 1990. The frequency and severity of the complications in the surviving neonates demonstrated the importance of prevention in this group of patients.

The main complication observed was seizure, mainly among newborns whose birth weight was $\geq 2500 \mathrm{~g}(\mathrm{p}=0.003)$. It is possible that the increased frequency of seizures in this group is related to the relative maturity of their CNS compared to low birth weight infants.

Neonates with birth weight $<1500 \mathrm{~g}$ presented a significantly higher frequency of intracranial hemorrhage. Because this group, whose brain is extremely vulnerable, presents several risk factors for intracranial hemorrhage, we considered it difficult to accurately assess the role of bacterial meningitis in the genesis of the hemorrhagic process.

Ventriculitis is a frequent complication of neonatal meningitis and is reported in 40 to $90 \%$ of the cases $^{14}$, especially in infants with persistent bacteria in the CSF. The frequency of ventriculitis observed in our patients $(10,3 \%)$ was relatively low, which suggests that the antibiotic used in the treatment was effective. Hydrocephaly is often associated with ventriculitis or intraventricular hemorrhage.

The association between positive CSF culture and the presence of complications or death has been reported by other authors ${ }^{9,12}$. It is likely that the presence of bacteria or their products in the CSF is related to the maintenance of the inflammatory cascade and central nervous system injury. Fifty per cent of the deaths occurred in neonates with a positive culture for enterobacteria, which is supported by other studies that show a variation in mortality according to the type of microorganism isolated from the CSF, with enterobacteria being the most virulent ${ }^{15,16}$. Krebs et al. ${ }^{8}$ observed significantly higher levels of IL- 6 in the CSF 
of neonates with meningitis due to gram-negative bacteria, suggesting a higher intensity of the inflammatory process in these newborns.

The brain abscess, reported in literature in $1 \%$ of meningitis cases caused by gram-negative bacteria ${ }^{17}$, was observed in $3,4 \%$ of our patients. It is known that the abscess may have a slow evolution and reach great proportions until it is detected. Sagittal sinus thrombosis and acute brain infarct are severe complications which are rarely diagnosed in vivo in cases of neonatal meningitis and, in most of the cases, they are reported as necropsy findings ${ }^{18}$. The higher incidence of these complications in our casuistic reflects the importance of conducting image exams systematically when examining neonates with bacterial meningitis.

The incidence of inappropriate $\mathrm{ADH}$ secretion, reported in up to $30 \%$ of neonates with meningitis ${ }^{10}$, was low in our patients.

There was no statistically significant difference in the duration of the treatment between the newborns presented birth weight $\geq 2500 \mathrm{~g}$ and the low birth weight newborns. Treatment of meningitis in the neonatal period is longer than therapy provided to all the other age groups because of the high severity of the disease in the newborn and the elevated risk of recurrence, which might affect 7 to $21 \%$ of the cases, even after a full treatment course $\mathrm{e}^{15,16}$. The authors recommend that the antibiotic therapy is maintained for at least 14 to 21 days after CSF culture becomes negative ${ }^{12,16}$. Additionally, we recommend the systematic CSF analysis before treatment withdrawal.

We conclude that the low frequency of neurological findings makes diagnosis of bacterial meningitis more difficult in low birth weight newborns that in infants whose birth weight was $\geq 2500 \mathrm{~g}$. The rate of complications was high in both groups, regardless of the birth weight. No significant association was observed between the occurrence of death and birth weight, although the mortality rate of low birth weight newborns was higher than the mortality rate found in infants whose birth weight was $\geq 2500 \mathrm{~g}$. Infants with positive CSF culture had a poorer prognosis.

\section{REFERENCES}

1. Krebs VLJ, Taricco LD. Fatores de risco para meningite bacteriana no recém-nascido. Arq Neuropsiquiatr 2004;62:630-634.

2. Hervás JA, Alomar A, Salvá F, Reina J, Benedí VJ. Neonatal sepsis and meningitis in Mallorca, Spain, 1977-1991. Clin Infect Dis 1993;16:719-724.

3. Gaynes RP, Edwards JR, Jarvis WR, Culver DH, Tolson JS, Martone WJ Nosocomial infections among neonates in high-risk nurseries in United States. National Nosocomial Infections Surveillance System. Pediatrics 1996;98:357-361.

4. Doctor BA, Newman N, Minich NM, Taylor HG, Fanaroff AA, Hack M. Clinical outcomes of neonatal meningitis in very-low-birth-weight infants. Clin Pediatr 2001;40:473-480.

5. Harvey D, Holt DE, Bedford H. Bacterial meningitis in the newborn: a prospective study of mortality and morbidity. Semin Perinatol 1999; 23:218-225.

6. Overall Jr JC. Neonatal bacterial meningitis: analysis of predisposing factors and outcome compared with matched control subjects. J Pediatr 1970;76:499-511.

7. Klein JO, Marcy SM. Bacterial sepsis and meningitis. In Remington JS, Klein JO (eds). Infectious diseases of the fetus and newborn infant. $4^{\text {th }}$ edition. Philadelphia: Saunders, 2001:601-656.

8. Krebs VLJ, Okay TS, Okay Y, Vaz FAC. Tumor necrosis factor- $\alpha$, interleukin- $1 \beta$ and interleukin- 6 in the cerebrospinal fluid of newborn with bacterial meningitis. Neonatal Intensive Care 2005;18:51-55.

9. Garges HP, Moody MA, Cotten CM, et al. Neonatal meningitis: what is the correlation among cerebrospinal fluid cultures, blood cultures, and cerebrospinal fluid parameters? Pediatrics 2006;117:1094-1100.

10. Feferbaum R, Vaz FAC, Krebs VLJ, Diniz EMA, Ramos SRTS, Manissadjian A. Meningite bacteriana no período neonatal: evolução clínica e complicações em 109 casos. Arq Neuropsiquiatr 1993;51:72-79.

11. Chang CJ, Chang WN, Huang LT, et al. Bacterial meningitis in infants: the epidemiology, clinical features, and prognostic factors. Brain Dev 2004;26:168-175.

12. Krebs VLJ, Diniz EMA, Vaz FAC, Marques-Dias MJ, Takiguti C, Ramos JLA. Meningite bacteriana neonatal: estudo prospectivo da evolução a longo prazo de 55 crianças. Arq Neuropsiquiatr 1996;54:75-81.

13. Heath PT, Yusoff NKN, Baker JC. Neonatal meningitis. Arch Dis Child Fetal Neonatal 2003;88:173-178.

14. Volpe JJ. Bacterial and fungal intracranial infections. In Volpe JJ. (Ed) Neurology of the newborn ( $4^{\text {th }}$ edition). Philadelphia: Saunders, 2001: 774-812.

15. Sarman G, Moise AA, Edwards MS. Meningeal inflammation in neonatal gram-negative bacteremia. Pediatr Infect Dis J 1995;14:701-704.

16. Dellagrammaticas HD, Christodoulou CH, Megaloyanni E, Papadimitriou M, Kapetanakis J, Kourakis G. Treatment of gram-negative bacterial meningitis in term neonates with third generation cephalosporins plus amikacin. Biol Neonate 2000;77:139-146.

17. Feferbaum R, Diniz EMA, Valente M, et al. Brain abscess by Citrobacter diversus in infancy: case report. Arq Neuropsiquiatr 2000;58:736-740.

18. Krebs VLJ, Chieffi LN, Ceccon MEJ, et al. Meningite neonatal por Streptococcus pyogenes e trombose de seio sagital. Arq Neuropsiquiatr 1998;56:829-832. 